\title{
Zinc partitioning between glass and silicate phases in historical and modern lead-zinc metallurgical slags from the Př́bram district, Czech Republic
}

\author{
Vojtěch Ettler ${ }^{\mathrm{a}, \mathrm{b} *}$, Zdenek Johan ${ }^{\mathrm{c}}$, Jean-Claude Touray ${ }^{\mathrm{b}}$, Emil Jelínek ${ }^{\mathrm{a}}$ \\ a Institute of geochemistry, mineralogy and mineral resources, Charles University, Albertov 6, 12843 Prague 2, Czech Republic \\ b DMES-ESEM, Institut des sciences de la Terre, université d'Orléans, rue Léonard-de-Vinci, 45072 Orléans, France \\ c BRGM, 3, avenue Claude Guillemin, 45060 Orléans, France
}

Received 22 May 2000; accepted 10 July 2000

\section{Communicated by Hubert Curien}

\begin{abstract}
Metallurgical slags of different ages resulting from Pb-metallurgy in the Př́bram district (Czech Republic) have been studied. The chemical analysis (EPMA) of melilite, clinopyroxene, olivine and glassy matrix showed the following $\mathrm{ZnO}$ concentrations (in wt. \%): 3.20-11.93 (melilite), 1.56 (clinopyroxene), 1.29-7.82 (olivine), 1.58-6.58 (glass). The Zn partition coefficient $D=C_{\mathrm{s}} / C_{\mathrm{l}}$ between crystallized phases and coexisting glass was calculated. The values obtained are: 1.96-2.16 (melilite), 0.41 (clinopyroxene) and 0.79-1.19 (olivine). The distribution of zinc between the crystalline phases and glass depends on the phase assemblage, which reflects the blast furnace charge and temperature, as well as the cooling conditions of slags. (c) 2000 Académie des sciences / Éditions scientifiques et médicales Elsevier SAS
\end{abstract}

Zn partitioning / metallurgical slag / Pb-metallurgy / Př́bram / Czech Republic

Résumé - Partage du zinc entre verre et phases silicatées dans des scories historiques et actuelles issues de la métallurgie du plomb dans le district de Přibram, République tchèque. Des scories métallurgiques, d'âges et d'origines différents, issues de la métallurgie du plomb et provenant du district de Př́bram en République tchèque ont été étudiées. L'analyse chimique (ME) de mélilite, de clinopyroxène, d'olivine et de matrice vitreuse a révélé les teneurs en $\mathrm{ZnO}$ suivantes (en \% massique) : 3,20-11,93 (mélilite), 1,56 (clinopyroxène), 1,29-7,82 (olivine), 1,58-6,58 (verre). Le coefficient de partage $\left(D=C_{\mathrm{s}} / C_{\mathrm{l}}\right)$ entre le cristal et le verre coexistant a été calculé pour chaque espèce. Les valeurs obtenues sont : 1,96-2,16 (mélilite), 0,41 (clinopyroxène) et 0,79-1,19 (olivine). La distribution du zinc entre les phases cristallines et le verre dépend de l'assemblage des phases reflétant la charge du fourneau et la température de fusion, ainsi que la vitesse de refroidissement des scories. (C) 2000 Académie des sciences / Éditions scientifiques et médicales Elsevier SAS

partage du zinc / scorie / métallurgie du plomb / Příbram / République tchèque

\section{Version abrégée}

\section{Introduction}

La pollution des sols et des eaux est souvent liée au stockage des déchets. Récemment, un grand nombre d'études décrivent le comportement des déchets dans des conditions superficielles [2, 7, 9, 10, 12, 14]. Les scories et les laitiers métallurgiques étudiés sont des déchets de fusion des sources de plomb primaires (minerais) et secondaires (batteries automobiles). Dans ces déchets, le zinc est piégé dans le verre résiduel, d'une part, dans la structure des silicates et des spinelles, d'autre part; par ailleurs, il existe sous forme de gouttelettes de ZnS. Le but de cet article est de caracté-

\footnotetext{
* Correspondence and reprints: ettler@mail.natur.cuni.cz
} 
riser la localisation minéralogique du zinc et de calculer son coefficient de partage entre silicates et verre dans des scories et laitiers d'âges différents, provenant de la région de Př́bram (figure) en République tchèque.

\section{Matériel et méthodologie}

Quatre types d'échantillons ont été étudiés (figure) : 1) type A - scorie du XIII ${ }^{\mathrm{e}}$ siècle, provenant du site archéologique de Bohutín, $7 \mathrm{~km}$ au sud-ouest de Př́́bram; 2) type $\mathbf{B}$ - laitier du XVIII ${ }^{\mathrm{e}}$ ou $\mathrm{XIX}^{\mathrm{e}}$ siècle, résultant du traitement d'un minerai de $\mathrm{Pb}$, prélevé sur les haldes à Lhota près de Příbram, au voisinage de l'usine métallurgique actuelle ; 3) type $\mathbf{C}$ - laitier du $\mathrm{XX}^{\mathrm{e}}$ siècle, résultant du traitement ancien des batteries automobiles, prélevé sur les haldes à Lhota près de Příbram ; 4) type D - laitier moderne (1998), fourni par le directeur de l'usine métallurgique, résultant du traitement actuel des batteries en utilisant la technologie Varta. Les échantillons ont été étudiés en lames minces et sections polies, par microscopie optique et au microscope électronique à balayage. Les analyses ont été réalisées à la microsonde électronique. Certains échantillons ont été étudiés par la diffraction des rayons X.

\section{Résultats et discussion}

Les silicates observés sont principalement des mélilites, des clinopyroxènes et des phases à structure type olivine. Ils sont accompagnés de spinelles et d'une phase vitreuse renfermant des inclusions métalliques sous forme de "gouttelettes", de taille souvent inférieure à $1 \mu \mathrm{m}$. Trois successions majeures ont été observées : 1) olivine $\rightarrow$ verre (type $\mathbf{A}$ ) ; 2) spinelle $\rightarrow$ mélilite $\rightarrow \quad$ clinopyroxène $\rightarrow$ verre à inclusions microscopiques de phases silicatées (type B); 3) spinelle $\rightarrow$ mélilite $\rightarrow$ olivine $\rightarrow$ verre (types $\mathbf{C}$ et $\mathbf{D}$ ).

Les clinopyroxènes n'apparaissent que dans le laitier de type $B$. Ils ne montrent aucune zonation chimique en $\mathrm{Zn}$ et peuvent être décrits comme les hédenbergites zincifères (1,56\% ZnO, tableau I) [6, 11]. Les mélilites sont les phases typiques des laitiers métallurgiques [3, 9]. Elles forment des cristaux prismatiques ou de type "spinifex ", sans zonation chimique. Pour les mélilites riches en $\mathrm{Zn}$ (laitier type $\mathrm{B} ; 11,93 \% \mathrm{ZnO}$, tableau I), leur composition chimique, calculée en termes extrêmes — åkermanite $\left(\mathrm{Ca}_{2} \mathrm{MgSi}_{2} \mathrm{O}_{7}\right)$, Fe-åkermanite $\left(\mathrm{Ca}_{2} \mathrm{FeSi}_{2} \mathrm{O}_{7}\right)$ et hardystonite $\left(\mathrm{Ca}_{2} \mathrm{ZnSi}_{2} \mathrm{O}_{7}\right)$ - est la suivante: $\mathrm{Ak}_{14} \mathrm{Fe}-\mathrm{Ak}_{37} \mathrm{Hard}_{49}$. Les phases à structure type olivine forment des cristaux dendritiques en aiguilles ou de type "spinifex". Le laitier du type A est principalement composé d'une fayalite zincifère à 7,82\% ZnO, tandis que les autres types de laitiers contiennent les olivines riches en $\mathrm{Ca}$ et proches de la Fe-monticellite (tableau I). Les spinelles sont les phases les plus riches en $\mathrm{Zn}$ (souvent plus de $18 \% \mathrm{ZnO}$ ). Par suite de leur cristallisation précoce, ils sont piégés par d'autres minéraux, surtout par les mélilites. N'ayant aucun contact direct avec le verre interstitiel, les spinelles ne sont pas pris en compte dans l'étude du partage de Zn. Dans le verre interstitiel, les concentrations en $\mathrm{Zn}$ peuvent atteindre $7 \% \mathrm{ZnO}$ environ (tableau I). Le verre interstitiel au contact des silicates a été analysé. Afin d'éliminer la contamination par les gouttelettes métalliques, seules les analyses reproductibles ont été retenues. La présence de $\mathrm{Zn}$ dans toutes les espèces étudiées suggère que $\mathrm{Zn}^{2+}$ se substitue à $\mathrm{Fe}^{2+}$ en site octaédrique, à cause des rayons ioniques similaires de ces deux cations $[4,5]$.

Les coefficients de partage (tableau II) ont été calculés en utilisant la relation [1]: $D=C_{\mathrm{s}} / C_{1}$, où $C_{\mathrm{s}}$ et $C_{1}$ sont les concentrations en $\mathrm{ZnO}$ (\% massique) respectivement dans une phase cristallisée (s) et dans le verre (1). Dans les conditions données, la valeur du coefficient de partage dépendra surtout de la structure et la composition chimique des phases cristallisées et du liquide résiduel [13]. Pour les mélilites de tous les types d'échantillons, les coefficients de distribution de $\mathrm{Zn}$ sont supérieurs à 1,9. Des valeurs similaires ont été notées par Wearing [15] pour les mélilites des laitiers de la métallurgie de Sn. Les clinopyroxènes indiquent une valeur de $D$ inférieure à l'unité $(D=0,4)$. Pour les phases de type olivine, les valeurs de $D$ varient autour de l'unité. Dans les scories du Moyen Âge, la fayalite (représentant la seule phase silicatée à l'état cristallin) est enrichie en $\mathrm{Zn}$ par rapport au verre environnant $(D=1,2)$. En revanche, les phases à structure type olivine provenant des laitiers C et $\mathrm{D}$ présentent des valeurs de $D$ de 0,9 et 0,8 respectivement.

\section{Conclusion}

Cette étude confirme que, pendant le refroidissement des laitiers métallurgiques, le zinc est piégé dans la structure des phases oxydées et silicatées (spinelle, mélilite, clinopyroxène, phases à structure type olivine), où il se substitue à $\mathrm{Fe}^{2+}$ en sites octaédriques. Le coefficient de partage du zinc entre phases cristallisées et verre varie entre 2 environ pour la mélilite et 0,4 pour le clinopyroxène. La distribution du zinc entre les phases cristallines et le verre dépend de l'assemblage des phases, reflétant la charge du fourneau et la température de fusion, ainsi que la vitesse de refroidissement des scories.

\section{Introduction}

Pollution of soil and water is often related to dumped wastes. In this respect, a large number of environmental studies are focused on the behaviour of waste under surface conditions. Municipal solid waste incinerator (MSWI) bottom ash, metallurgical slags and mine tail- 
ings may represent important pollution sources $[2,7,9$, $10,12,14]$. This article concerns $\mathrm{Pb}-\mathrm{Zn}$ metallurgical slags - a type of waste resulting from the fusion of primary and secondary Pb-sources. This material contains important amounts of heavy metals incorporated in crystallized and glassy phases.

During the metallurgical smelting process, the majority of recovered metals $(\mathrm{Pb}, \mathrm{Ag}, \mathrm{Cu})$ are concentrated in liquid form as nearly pure metal and/or as sulphide 'matte' at the bottom of the blast furnace. However, almost all the zinc is vaporized or dissolved in the liquid silicate slag floating on the dense matte and liquid metals [4]. In the silicate slag, zinc is present in three forms: (i) quenched sulphide droplets, (ii) silicates and oxides and (iii) silicate glass. This article is devoted to crystal/melt partitioning of $\mathrm{Zn}$ in slag samples of different ages, resulting from metallurgical activity in the region of Príbram (Czech Republic). The basic hypothesis is that, because of quenching, the diffusion rate of zinc in melt is negligible. Consequently, in the same sample, the apparent partition coefficients may be calculated for different stages of the crystallization sequence knowing respectively the $\mathrm{Zn}$ concentrations in the crystalline solid phase and coexisting glass.

\section{Material and methods}

Four different slag types were studied, originating from different sites (figure) located in the mining district of Př́bram, known for its polymetallic vein deposits (with mainly $\mathrm{Ag}, \mathrm{Pb}, \mathrm{Zn}, \mathrm{As}, \mathrm{Sb}$ and $\mathrm{Sn}$ ):

- A-type slag: dated from XIII ${ }^{\text {th }}$ century, it has been found in archaeological excavations near Bohutín, about $7 \mathrm{~km}$ southwest of Príbram; this slag results from the smelting of $\mathrm{Pb}-\mathrm{Ag}$ ores in primitive blast furnaces, probably at a relatively low temperature (use of charcoal for heating) and without a Ca source in the furnace charge; samples occur as fragments of vitrified material of several centimetres in size;

- B-type slag: it is one or two centuries old (XVIIIth to $\mathrm{XIX}^{\text {th }}$ century); it derives from $\mathrm{Pb}$-ore processing and smelting; slag casts (size about $30 \mathrm{~cm}$ ) have a cone-like shape and sometimes a sulphide 'matte' at their base; they were sampled on the dumps at Lhota near Príbram, in the vicinity of the Příbram smelter;

- C-type slag: only few decades old (XX ${ }^{\text {th }}$ century); it is a by-product of past processing of car batteries and forms 'eaves-shaped' elongated blocks about $30 \mathrm{~cm}$ in length; it has been sampled on the dumps at Lhota near Príbram;

- D-type slag: modern slag results from the present-day battery processing and smelting: a huge sample was provided in December 1998 by the courtesy of the director of Příbram smelter (Kovohut Příbram, a.s.).

Thin and polished sections of slag samples were studied in transmitted and reflected light by optical microscopy; then by a Jeol JSM 6400 scanning electron microscope (SEM, ESEM-université d'Orléans). Solid phase analyses were carried out using a Cameca SX-50 electron-microprobe analyser (EPMA, BRGM-CNRS Orléans) under the following analytical conditions: accelerating voltage $15 \mathrm{kV}$, beam current $12 \mathrm{nA}$, counting time $8 \mathrm{~s}$ on peak and background except for $\mathrm{Pb}$ $(16 \mathrm{~s})$; set of standards: albite $(\mathrm{Si}, \mathrm{Na}), \mathrm{K}$-feldspar (K), forsterite $(\mathrm{Mg})$, hematite $(\mathrm{Fe})$, andradite $(\mathrm{Ca})$, barite $(\mathrm{Ba})$, apatite $(\mathrm{P})$, zincite $(\mathrm{Zn})$, galena $(\mathrm{Pb}), \mathrm{Cr}_{2} \mathrm{O}_{3}(\mathrm{Cr}), \mathrm{NiO}$ $(\mathrm{Ni})$, pyrite $(\mathrm{S})$, vanadinite $(\mathrm{Cl})$, synthetic $\mathrm{MnTiO}_{3}(\mathrm{Ti}$, $\mathrm{Mn}$ ) and $\mathrm{Al}_{2} \mathrm{O}_{3}(\mathrm{Al})$. In some cases, the phase composition of studied samples was determined using X-ray powder diffractometer (XRD) with $\mathrm{Cu} \mathrm{K \alpha}$ radiation; the measurements were done in step-scan mode over the
Figure. Geographic location of mining district of Př́bram with sampling sites.

Figure. Position géographique du district minier de Prŕbram et localisation des sites d'échantillonnage.

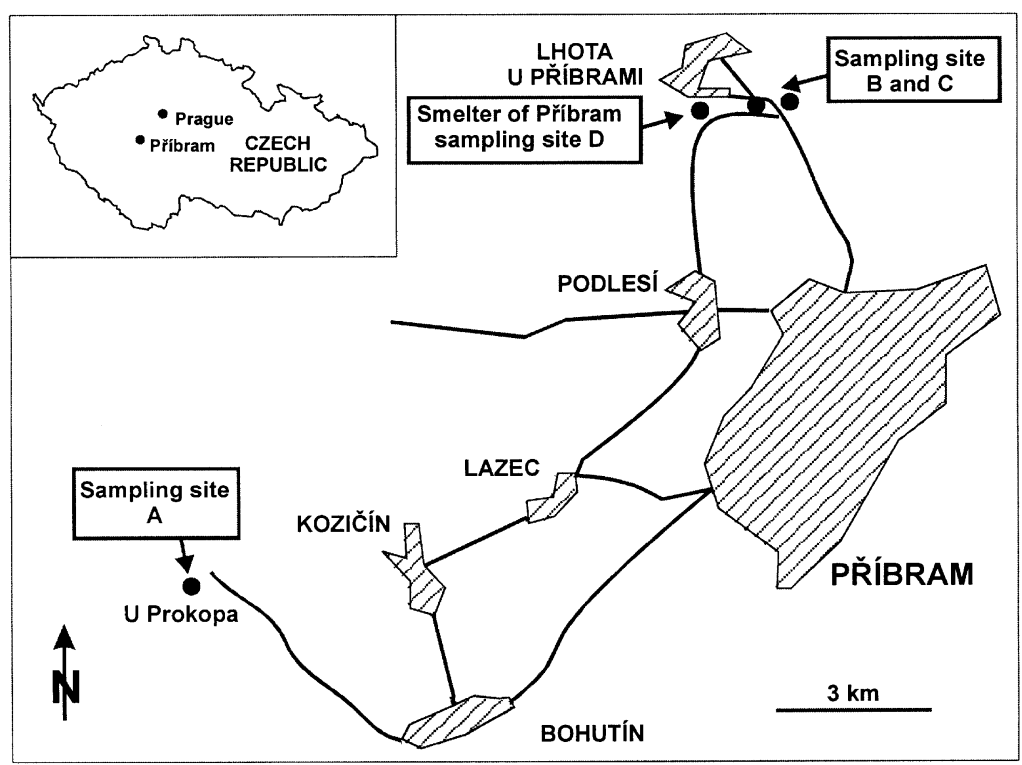


range $5-80^{\circ} 2 \theta$ in steps of $0.01^{\circ}$ and with a counting time of $10 \mathrm{~s}$.

\section{Results and discussion}

\subsection{Mineralogy}

\subsubsection{Overview}

High-temperature $\mathrm{Ca}-\mathrm{Fe}$ aluminosilicates crystallizing at about $1300{ }^{\circ} \mathrm{C}$ (melilites, clinopyroxenes, olivinetype phases) accompanied by oxides (spinels), rare sulphides and metallic phases are the major crystallized components of the studied slags. Only oxides and silicates are the subject of this paper.

Three major phase assemblages were observed, with the following crystallization sequences: 1) olivine $\rightarrow$ glass (A-type slag); 2) spinel $\rightarrow$ melilite $\rightarrow$ clinopyroxene $\rightarrow$ interstitial glass with sub-microscopic inclusions of silicates (B-type slag); 3) spinel $\rightarrow$ melilite $\rightarrow$ olivine $\rightarrow$ glass (C-type and $\mathbf{D}$-type slags). The main differences in mineralogical and chemical composition of the different slags are:

- absence of Ca-rich silicates (clinopyroxene, melilite) in the A-type slag (lack of addition of $\mathrm{CaCO}_{3}$ as a melting agent in the Middle Ages) while, at least, one of these Ca-bearing phases occurs in other types of slag;

- presence of minor $\mathrm{Cl}$ concentration in the glass of C-type slag, resulting from the fusion of car batteries with their PVC cases;

- occurrence of Na-bearing phases (melilites in $\mathbf{C}$ and D-type) due to the use of sodium compounds in the Harris refining technological process from 1941 to 1997 [8].

\subsubsection{Clinopyroxenes}

Clinopyroxenes were observed only in B-type slags, in the central parts of casts where cooling was relatively slow. They occur as green phenocrysts with a maximum length of several hundreds of microns. The compositional profile through a clinopyroxene crystal reveals a slight zoning with a border enriched in Fe and $\mathrm{Al}$ and depleted in Si and Mg. However, there is no difference in $\mathrm{Zn}$ concentration between the crystal core and the rim. The composition of the studied clinopyroxene is rather complex (table I). A hedenbergite end-member $\left(\mathrm{CaFeSi}_{2} \mathrm{O}_{6}\right)$ is the prevailing component with 1.56 wt. \% ZnO. Essene and Peacor [6] plotted the Zn-bearing clinopyroxenes into the compositional space of three end-members: diopside + hedenbergite $\left(\mathrm{Ca}(\mathrm{Mg}, \mathrm{Fe}) \mathrm{Si}_{2} \mathrm{O}_{6}\right)$ - johannsenite $\left(\mathrm{CaMnSi}_{2} \mathrm{O}_{6}\right)$ - petedunnite $\left(\mathrm{CaZnSi}_{2} \mathrm{O}_{6}\right)$. Referring to these end-members, the crystal-chemical formula of the studied clinopyroxene can be expressed as $(\mathrm{Di}+\mathrm{Hd})_{90} \mathrm{Jh}_{5} \mathrm{Pe}_{5}$.

\subsubsection{Melilites}

Melilites are common in slags [3, 9]. In the studied samples they occur either as comb-shaped irregular prisms (harrisitic crystals), or as phenocrysts of hundreds of $\mu \mathrm{m}$ in size, without chemical zonation. Their composition is given in table $I$. They contain mainly iron-åkermanite $\left(\mathrm{Ca}_{2} \mathrm{FeSi}_{2} \mathrm{O}_{7}\right)$ and åkermanite $\left(\mathrm{Ca}_{2} \mathrm{MgSi}_{2} \mathrm{O}_{7}\right)$, with an important amount of hardystonite $\left(\mathrm{Ca}_{2} \mathrm{ZnSi}_{2} \mathrm{O}_{7}\right)$. The melilite with the highest $\mathrm{ZnO}$ content corresponds to a B-type slag and its composition, taking into account the above-mentioned end-members, can be expressed as $\mathrm{Ak}_{14} \mathrm{Fe}-\mathrm{Ak}_{37} \mathrm{Hard}_{49}$.

\subsubsection{Olivine-type phases}

Olivine-type phases are the last silicates crystallizing from the liquid in the $\mathbf{C}$ - and D-type slags. They form small needles or dendrites, often difficult to analyse by EPMA, due to their size. However, in A-type Middle Ages slag, olivine appeared early and its chemical composition corresponds to Zn-bearing fayalite with up to 7.82 wt. \% of $\mathrm{ZnO}$ (the fayalite structure has been confirmed by XRD). Other Zn-bearing fayalites found by Chaudhuri and Newesely [4] in Harz Mountain metallurgical slags contain up to 12.75 wt. \% of $\mathrm{ZnO}$. $\mathrm{Zn}$ substitutes for $\mathrm{Fe}^{2+}$ in the fayalite crystal structure. In CaO-rich slags, 'olivine-type' phases are similar to Fe-monticellite (confirmed by XRD) (table I). They contain lower $\mathrm{Zn}$ concentrations than fayalite present in the A-type slags (table I).

\subsubsection{Spinels}

Spinels, when present, appear early in the crystallization sequence forming euhedral crystals of several $\mu \mathrm{m}$ in size. They are embedded in later phases such as melilites. Spinels with coexisting glass were not observed and therefore they are not suitable for crystal/liquid partitioning calculation. They concentrate important amounts of zinc (> 18 wt. \% of $\mathrm{ZnO}$ ), are very often zoned, and correspond to a complex solid solution of spinel, hercynite, gahnite, and magnetite, with elevated percentages of Cr-bearing end-members for modern slags.

\subsubsection{Metallic phases and sulphides}

Metallic phases and sulphides are important concentrators of heavy metals in slags, where they occur as inclusions trapped in glass. The EPMA study revealed the presence of metallic $\mathrm{Pb}, \mathrm{Cu}$ and $\mathrm{Sb}$, galena, sphalerite/wurtzite, pyrrhotite, bornite, and different complex alloys and inter-metallic compounds of Sb, Sn, $\mathrm{Cu}, \mathrm{As}$ and $\mathrm{Pb}$.

\subsubsection{Glass}

Glass, recognizable by its amorphous character, exists in two different locations: (i) at the chilled margin and (ii) as interstitial glass between silicate crystals. With respect to the crystal/melt partition study, only glass in direct contact with clinopyroxene, melilite and olivine has been taken into consideration (table I). In order to eliminate contamination by sub-microscopic inclusions 
Table I. Selected microprobe analyses of crystalline phases and glass. The structural formulae of crystalline phases were calculated on the basis of 4 (olivine), 6 (clinopyroxene) and 7 (melilite) oxygens; (A: Middle Ages slag, B: slag from ore processing, C: slag from historical battery processing, D: slag from modern battery processing).

Tableau I. Analyses à la microsonde électronique des phases cristallines et du verre. La formule structurale des phases cristallines a été calculée sur la base de 4 (olivine), 6 (clinopyroxène) et 7 (mélilite) oxygènes; (A : scorie du Moyen Âge, B : laitier du traitement des minerais, $\mathbf{C}$ : laitier du traitement historique des batteries, $\mathbf{D}$ : laitier du traitement actuel des batteries).

\begin{tabular}{|c|c|c|c|c|c|c|c|c|c|c|c|c|}
\hline slag type & A & A & B & B & B & B & C & $\mathrm{C}$ & $\mathrm{C}$ & $\mathrm{D}$ & $\mathrm{D}$ & $\mathrm{D}$ \\
\hline phase & olivine & glass & clinopyroxene & glass & melilite & glass & melilite & glass & olivine & melilite & glass & olivine \\
\hline $\mathrm{SiO}_{2}$ & 31.13 & 39.44 & 42.34 & 31.54 & 39.67 & 30.77 & 39.84 & 30.39 & 31.35 & 39.54 & 31.99 & 30.16 \\
\hline $\mathrm{Al}_{2} \mathrm{O}_{3}$ & 0.36 & 5.58 & 8.66 & 1.88 & 1.77 & 0.20 & 5.38 & 15.62 & 0.04 & 7.44 & 6.25 & 0.89 \\
\hline $\mathrm{FeO}$ & 45.39 & 14.58 & 21.72 & 45.67 & 8.10 & 51.32 & 10.84 & 30.80 & 39.20 & 8.37 & 29.66 & 42.52 \\
\hline $\mathrm{MnO}$ & 8.22 & 2.45 & 1.30 & 3.87 & 0.71 & 4.67 & 0.56 & 0.66 & 2.72 & 0.04 & 0.92 & 1.60 \\
\hline $\mathrm{Na}_{2} \mathrm{O}$ & 0.11 & 0.47 & 0.08 & 0.24 & 0.45 & 0.10 & 2.06 & 0.71 & 0.11 & 2.57 & 0.81 & 0.13 \\
\hline $\mathrm{K}_{2} \mathrm{O}$ & 0.17 & 1.43 & 0.09 & 0.45 & 0.20 & 0.03 & 0.11 & 0.28 & 0.03 & 0.11 & 0.43 & 0.04 \\
\hline $\mathrm{BaO}$ & 0.66 & 4.56 & 0.00 & 0.00 & 0.00 & 0.00 & 0.00 & 1.05 & 0.00 & 0.00 & 0.81 & 0.16 \\
\hline $\mathrm{P}_{2} \mathrm{O}_{5}$ & 0.06 & 0.65 & 0.33 & 0.23 & 0.33 & 0.05 & 0.38 & 0.49 & 0.23 & 0.45 & 0.50 & 0.32 \\
\hline $\mathrm{Cr}_{2} \mathrm{O}_{3}$ & 0.12 & 0.00 & 0.04 & 0.00 & 0.00 & 0.02 & 0.00 & 0.00 & 0.00 & 0.06 & 0.00 & 0.03 \\
\hline $\mathrm{NiO}$ & 0.03 & 0.00 & 0.00 & 0.03 & 0.00 & 0.00 & 0.00 & 0.00 & 0.00 & 0.00 & 0.12 & 0.18 \\
\hline Total & 99.47 & 99.45 & 101.35 & 99.22 & 100.04 & 101.56 & 99.81 & 99.75 & 99.79 & 100.01 & 98.06 & 99.51 \\
\hline $\mathrm{Si}$ & 1.035 & & 1.708 & & 1.998 & & 1.936 & & 0.993 & 1.888 & & 0.977 \\
\hline $\mathrm{Ti}$ & 0.000 & & 0.024 & & 0.000 & & 0.003 & & 0.000 & 0.000 & & 0.000 \\
\hline $\mathrm{Al}$ & 0.000 & & 0.412 & & 0.105 & & 0.308 & & 0.000 & 0.419 & & 0.000 \\
\hline $\mathrm{Fe}$ & 1.262 & & 0.733 & & 0.341 & & 0.441 & & 1.038 & 0.334 & & 1.152 \\
\hline $\mathrm{Mn}$ & 0.232 & & 0.044 & & 0.030 & & 0.023 & & 0.073 & 0.001 & & 0.044 \\
\hline $\mathrm{Mg}$ & 0.223 & & 0.118 & & 0.131 & & 0.167 & & 0.125 & 0.251 & & 0.205 \\
\hline $\mathrm{Ca}$ & 0.018 & & 0.973 & & 1.866 & & 1.803 & & 0.745 & 1.774 & & 0.608 \\
\hline $\mathrm{Na}$ & 0.000 & & 0.006 & & 0.044 & & 0.194 & & 0.000 & 0.238 & & 0.000 \\
\hline K & 0.000 & & 0.000 & & 0.013 & & 0.007 & & 0.000 & 0.007 & & 0.000 \\
\hline $\mathrm{Cr}$ & 0.003 & & 0.001 & & 0.000 & & 0.000 & & 0.000 & 0.000 & & 0.001 \\
\hline $\mathrm{Ni}$ & 0.001 & & 0.000 & & 0.000 & & 0.000 & & 0.000 & 0.000 & & 0.005 \\
\hline
\end{tabular}

of $\mathrm{ZnS}$, only reproducible data for a given glass/crystal pair have been considered.

\subsection{Zinc site occupancy}

Simplified general formulae of studied phases are the following: $X Y Z_{2} \mathrm{O}_{6}$ (clinopyroxene), $X_{2} Y Z_{2} \mathrm{O}_{7}$ (melilite) and $X \mathrm{XZO}_{4}$ (olivine), where $X$ is a large cation, eight co-ordinated, $Y$ an octahedral intermediate-sized cation, and $Z$ a tetrahedral small-sized cation [15]. In all silicates (clinopyroxene, melilite and olivine) $\mathrm{Zn}^{2+}$ (ionic radius: $0.74 \AA$ ) will very likely prefer the octahedral $Y$ sites and substitute for $\mathrm{Fe}^{2+}$ (ionic radius: $0.76 \AA$ ) [4]. In all these relevant cases, a limited miscibility between $\mathrm{Fe}$ and $\mathrm{Zn}$ end-members may be supposed. For example, the solid solution series between $\mathrm{Fe}_{2} \mathrm{SiO}_{4}$ (fayalite) and $\mathrm{Zn}_{2} \mathrm{SiO}_{4}$ (willemite) extends from the fayalite endmember up to $17 \mathrm{~mol} \% \mathrm{Zn}_{2} \mathrm{SiO}_{4}$ (i.e. 13.37 wt. \% of $\mathrm{ZnO)}[5]$.

\subsection{Partition coefficients}

The partition (or distribution) coefficient is defined as $D=C_{\mathrm{s}} / C_{\mathrm{l}}$, where $C_{\mathrm{s}}$ is the concentration of the studied element in the crystal and $C_{1}$ is its concentration in the liquid [1]. Partition coefficients for $\mathrm{Zn}$ (table II) were calculated using the formula $D=(\mathrm{ZnO}$ (wt. \%) in crystal/ZnO (wt. \%) in glass). In general, for a given pressure, the partition coefficient depends (i) on the structure and chemical composition of both melts and crystals and (ii) on temperature (about $1300{ }^{\circ} \mathrm{C}$ for recent slags but lower for slags of the Middle Ages). The 'structural-compositional' dependence is the most important factor [13].

Although the partition coefficient for spinels was impossible to calculate, one may suppose $D$ values sig-

Table II. ZnO crystal/glass partition coefficients.

Tableau II. Les coefficients de partage de $\mathrm{ZnO}$ entre cristaux et verre.

\begin{tabular}{lcccc}
\hline slag type & $\mathrm{A}$ & $\mathrm{B}$ & $\mathrm{C}$ & $\mathrm{D}$ \\
\hline $\mathrm{D}$ (cpx-glass) & - & 0.41 & - & - \\
$\mathrm{D}$ (mel-glass) & - & 2.16 & 2.15 & 1.96 \\
$\mathrm{D}$ (ol-glass) & 1.19 & - & 0.91 & 0.79 \\
\hline
\end{tabular}


nificantly higher than 1 , with relevance to the compatible behaviour of $\mathrm{Zn}$ with spinel structure.

Melilites show $D$ values of about 2. Similar values for $\mathrm{Zn} \mathrm{crystal/liquid} \mathrm{partition} \mathrm{coefficients} \mathrm{were} \mathrm{also}$ obtained by Wearing [15] for melilites from tin slags. Both these results reveal that $\mathrm{Zn}$ is compatible with melilite structure and hence its concentration in the residual melt will be depleted during melilite crystallization. However, due to a moderately high $D$ value, enough $\mathrm{Zn}$ will remain in the liquid to allow a significant trapping of this element in later crystallized phases.

The partition coefficient for clinopyroxene shows a lack of compatibility of $\mathrm{Zn}$ with its structure $(D=0.4)$. In agreement with the data of Wearing [15], the melt becomes enriched in Zn during the clinopyroxene crystallization. Despite this 'incompatibility', a significant amount of $\mathrm{Zn}$ enters into the clinopyroxene structure. According to Morimoto [11], the Zn concentration, given in this study $(1.56 \mathrm{wt} . \% \mathrm{ZnO}$, i.e. 0.05 cations per formula unit), is sufficient to permit use of the name 'zincian hedenbergite' for this phase.

The partition coefficient calculated for olivine is close to 1 . Slightly compatible behaviour was noticed for $\mathrm{Zn}$ in the system fayalite-melt from the XIII ${ }^{\text {th }}$ century slag $(D=1.2)$ while in the case of olivine-type phases from C- and D-type slags, partition coefficients are respectively 0.9 and 0.8. For fayalites in a copper slag, Wearing [15] calculated $\mathrm{Zn}$ partition coefficients reaching
2.9. This discrepancy may result from differences in fayalite growth rates, variation of $D$ with melt structure, etc.

\section{Conclusions}

This study confirms that during the cooling of metallurgical slags, $\mathrm{Zn}$ enters into the crystal structures of oxides and silicates (spinel, melilite, clinopyroxene and olivine), due to the substitution for $\mathrm{Fe}^{2+}$ in octahedral sites. The distribution of zinc between silicates and glass depends on the phase assemblage (nature and probably texture) which reflects blast furnace charge and temperature, as well as the cooling conditions of the slags. The calculated crystal/glass Zn partition coefficient shows a rather compatible behaviour with respect to melilite, and rather incompatible behaviour with clinopyroxene while olivine-type phases display a $D$ value close to 1.

During the cooling of the melt, zinc enters first into the spinel structure. Melilite starts to nucleate simultaneously with spinel and also concentrates $\mathrm{Zn}$. In contrast, the calculated $D$ values for late crystallized phases (clinopyroxene in the B-type slag or olivine in $\mathrm{C}$ - and D-type slags) are lower than 1 , indicating $\mathrm{Zn}$ enrichment in the residual melt.

Acknowledgements. We thank Zdeněk Kunický, the director and Karel Vurm, the ecological technician, of the smelter (Kovohutě Př́bram a.s.) for providing slag samples. This research work was supported by BRGM, University of Orléans and by a grant of the Ministry of Education of the Czech Republic to Charles University in Prague (no. 24-313005).

\section{References}

[1] Albarède F., Bottinga Y., Kinetic disequilibrium in trace element partitioning between phenocrysts and host lava, Geochim. Cosmochim. Acta 36 (1972) 141-156.

[2] Baranger P., Azaroual M., Lanini S., Piantone P., Freyssinet P., Modelling the weathering of a bottom-ash heap, in: Méhu J., GrelierVolatier L., Burleigh T. (Eds.), Waste stabilization and environment, Lyon, France, 1999, pp. 79-83.

[3] Butler B.C.M., Al-rich pyroxene and melilite in a blast furnace slag and a comparison with the Allende meteorite, Mineral. Mag. 41 (1977) 493-499.

[4] Chaudhuri J.N.B., Newesely H., Mineralogical characterization of old Harz Mountain slags, Can. Metall. Quart. 32 (1993) 1-12.

[5] Ericsson T., Filippidis A., Cation ordering in the limited solid solution $\mathrm{Fe}_{2} \mathrm{SiO}_{4}-\mathrm{Zn}_{2} \mathrm{SiO}_{4}$, Am. Mineral. 71 (1986) 1502-1509.

[6] Essene E.J., Peacor D.R., Petedunnite $\left(\mathrm{CaZnSi}_{2} \mathrm{O}_{7}\right)$, a new zinc clinopyroxene from Franklin, New Jersey, and phase equilibria for zincian pyroxenes, Am. Mineral. 72 (1987) 157-166.

[7] Eusden J.D., Eighmy T.T., Hockert K., Holland E., Marsella K., Petrogenesis of municipal solid waste combustion bottom ash, Appl. Geochem. 14 (1999) 1073-1091.

[8] Hampejs V., Jubilee of the smelter of Př́ibram, Oblastní muzeum Podbrdska v Příbrami, 1971, 268 p. (in Czech).
[9] Kucha H., Martens A., Ottenburgs R., De Vos W., Viaene W., Primary minerals of $\mathrm{Zn}-\mathrm{Pb}$ mining and metallurgical dumps and their environmental behaviour at Plombières, Belgium, Environ. Geol. 27 (1996) 1-15.

[10] Mandin D., Van der Sloot H.A., Gervais C., Barna R., Méhu J., Valorization of lead-zinc primary smelters slags, in: Goumans J.J.J.M., Senden G.J., Van der Sloot H.A. (Eds.), Waste materials in construction, Houthem, St. Gerlach-Netherlands, 1997, pp. 617-629.

[11] Morimoto N., Nomenclature of pyroxenes, Mineral. Mag. 52 (1988) 535-550.

[12] Morin G., Ostergren J.D., Juillot F., Ildefonse P., Calas G., Brown G.E., XAFS determination of the chemical form of lead in smelter-contaminated soils and mine tailings: Importance of adsorption processes, Am. Mineral. 84 (1999) 420-434.

[13] Mysen B.O., Virgo D., Trace element partitioning and melt structure: an experimental study at $1 \mathrm{~atm}$. pressure, Geochim. Cosmochim. Acta 44 (1980) 1917-1930.

[14] Shu J., Bradshaw A.D., The containment of toxic wastes. I. Long term metal movement in soils over a covered metalliferous waste heap at parc lead-zinc mine, North Wales, Environ. Pollut. 90 (1995) $371-377$.

[15] Wearing E., Crystal-liquid partition coefficients for pyroxene, spinels, and melilites, in slags, Mineral. Mag. 47 (1983) 335-345. 